\title{
STRENGTHENING FINANCIAL TECHNOLOGY REGULATION TO EMPOWERMENT FINANCIAL INCLUSIVE
}

\author{
Lastuti Abubakar, Tri Handayani \\ Economic Law Department, Faculty of Law, Universitas Padjadjaran \\ lastuti.abubakar@unpad.ac.id \\ tri.handayani@unpad.ac.id
}

\begin{abstract}
After the global crisis at 2008; Financial Inclusion became a focus in many international forums including developing countries and Indonesia. Refers to international best practice, the solution is made: the national financial inclusion strategies that conducted among other things such as launch a certain programs such as branchless banking and peer to peer lending are the solutions has made. One of the financial inclusive principles is technological innovation to expand public access using financial technology to reach financial systems. This research aims to study and analyze fintech regulation in Indonesia to empower the financial inclusive. Research method is used a normative juridical and descriptive analytics specification. Data has analyzed in a qualitative juridical. The results showed that Fintech has a role in broaden the access for community to financial systems so that it can be a tool for poverty alleviation and economic equality. Likewise, to strengthening and rearrange Fintech regulation is needed due to overcome the obstacles such as the misuse of personal data, the growth of shadow economy and consumer losses. Therefore, it is required a comprehensive regulation, cooperation between authorities and institutions in order that Fintech can be optimally empower the financial inclusion
\end{abstract}

Keywords: Financial Technology; Financial Inclusion; Strengthening Regulation's

\section{Introduction}

Financial Inclusion is become trend post 2008 crisis, especially crisis has impact to the group at the bottom of the pyramid (low income and irregular, living in remote areas, disabled people, workers who do not have legal identity documents, and Peoples suburbs) are generally unbanked. This group was reported in a very high number outside in developed countries. At the G20 Pittsburgh Summit 2009, G20 members agreed on the need for increased financial access for the group, which was highlighted at the Toronto Summit in 2010, after being released of 9 Principles for Innovative Financial Inclusion as guidelines for the financial inclusion development. These principles are leadership, diversity, innovation, protection, empowerment, cooperation, knowledge, proportionality, and framework. Since then, many international forum that focus its activities on finance inclusion include World Bank, APEC, Asian development Bank (ADB), Alliance for financial Inclusive (AFI), including international organization such as 
Banks for International Settlement (BIS) and Financial Action Task Force (FATF), including developing countries and Indonesia. ${ }^{1}$

Financial inclusion may be defined as the process of ensuring access to financial services and adequate credit where needed by vulnerable groups such as weaker sections and low income at an affordable cost. Financial inclusion includes access to financial products and services like banks accounts, insurance, remittance \& payment services, financial advisory services etc. ${ }^{2}$ In Indonesia, financial inclusive is a national strategy to empower the economic growth through income distribution properly, reduction the poverty, and the stability of the financial system. ${ }^{3}$ Financial Inclusion is an urgent need for Indonesia because the number of adults who have access to formal financial institutions is lower than those who do not have access. Based on 2014 Global Index data, around $36 \%$ of the adult population in Indonesia have access to formal financial institutions. It is expected that by the end of 2019 it will reach $75 \%$. ${ }^{4}$ Therefore, one of the focuses in the Master Plan of the Indonesian Financial services sector (MPJSKI) is to realize the financial autonomy of the inclusive financial community that aims to support the efforts to increase the equality in development. ${ }^{5}$ To realize a financial inclusion, the Government of Indonesia use comprehensive approach with Presidential Decree No. 82 of 2016 regarding the National Strategy for Financial Inclusion (SNKI). According SNKI, it is emphasized that financial inclusion is an important component in the process of social and economic inclusion that has a role to support economic growth, create the financial system stability, support poverty reduction programs, and reducing gaps among the individuals and between regions. Refers to SNKI, finance inclusion is defined as a condition when every member of the community has access to a variety of quality formal financial services in a timely, smooth and safe manner with affordable costs in accordance with their needs and abilities in order to improve the welfare of the community. Furthermore, a financial inclusion system is realized through public access to financial services will improve economic capacity and ultimately is a solution to reduce poverty and economic gaps. Wider access to financial services is important stage to increase the participation of all levels of society in the economy. Wider access to financial services is

Bank Indonesia, "Stabilitas Sistem Keuangan- Keuangan Inklusif- Apa, Mengapa, Bagaimana dan Siapa."https://www.bi.go.id/id/perbankan/keuanganinklusif/Indonesia/Contents/Default.aspx

2 Tabitha Durai, "Digital Finance And Its Impact On Financial Inclusion," Journal of Emerging Technologies and Innovative Research (JETIR) 6, Issue $1: 122$

3 I Made Sanjaya dan Nursechafia, “Inklusi Keuangan dan Pertumbuhan Inklusif : Analisis Antara Provinsi di Indonesia,"Buletin Ekonomi Moneter dan Perbankan 18, No. 3 (2016): 283-284.

4 Lampiran Peraturan Presiden No 82 Tahun 2016 Tentang Strategi Nasional Keuangan Inklusif, p. 8.

5 Otoritas Jasa Keuangan, Master Plan Sektor Jasa Keuangan Indonesia 2015-2019 (Jakarta: OJK), 63. 
important in an effort to increase the participation of all levels of society in the economy. Until now, the growth of the financial sector in Indonesia has not been followed by adequate public access to financial services such as access to payment transaction instruments; access to savings; and access to credit / financing. Therefore efforts are needed so that access to these financial institutions can be achieved. International practice shows that the way out to overcoming obstacles in realizing finance inclusive is developed certain programs such as branchless banking, basic saving, education, peer to peer lending, etc. Regarding the access to the financial institution, banking and capital markets sectors have already launched the programs, Digital Banking services. The utilize of Automated Teller Machines (ATM) and electronic money shown from charts is still increasing from year to year. In addition, OJK has issued POJK No. 19 / POJK.03 / 2014 concerning Financial Services without Offices in order to Financial inclusion. This regulation aims to broaden the access to financial services both banking or another financial services. In its development, innovation in the financial sector through the use of information technology gave improvement to the financial service product such as fintech that is still developing in Indonesia rapidly. The existence of Fintech is also harmonies with the innovation principle from SKNI, which is to empower technological and institutional innovation to broaden access and the utilize of financial system. Fintech metamorphosis that developed in the financial sector is an important instrument in accelerating financial inclusion as one of the national development acceleration program. ${ }^{6}$

According to the Press Release No. SP18 / DHMS / OJK / 2019, OJK continues to drive Fintech Lending industry to grow and promote financial inclusion, especially by expanded the access to Micro Small and Medium Enterprise (MSME) capital. Regarding the policy to support the funding of MSMEs, the OJK has two choices, namely to encourage Fintech Lending to increase productive funding capacity (quality) or encourage the massive registration of productive Fintech Lending (quantity). ${ }^{7}$ Based on Fintech statistics that issued by OJK as of March 2019, the aggregate amount of loans in Java and outside Java was Rp.32,200,470,348,514 with a return success rate of $97.38 \%$ and default of $2.62 \%$. The statistics show a significant increase since December 2018 amounting to Rp.222,666,069,500,288. Loans increase every

\footnotetext{
6 Fitri Rusdiana Sari, "Peran Inklusi Keuangan melalui Integrasi Fintech dalam Stabilitas Sistem keuangan Indonesia,” Jurnal Ekonomi Kuantitatif Terapan 11, No. 2 (2018): 245.

7 Otoritas Jasa Keuangan, Master Plan Sektor Jasa Keuangan Indonesia 2015-2019 (Jakarta: OJK), 63.
} 
month in a range of 3-4 trillion per month. So, Fintech has the opportunity to expose the free access to finance institution. ${ }^{8}$

The growth of Fintech lending has a greater numbers and continues to increase from time to time. Based on OJK data, currently the numbers of Fintech Lending Companies that have permits and are OJK registered; in April 2019 are 106 companies. ${ }^{9}$ The number of Fintech lending companies that have licenses and are registered with the OJK is much smaller than the number of illegal Fintech companies, namely 947 companies. In addition, As of April 2019, the OJK Investment Task Force found 144 entities that conduct Fintech Lending business activities are not registered or have business licenses from OJK. Activity 144 of this entity violates POJK No. 77 / POJK.01 / 2016 concerning Information Technology-based Money Borrowing Services (POJK Fintech lending) that have the potential to harm the people. At the same time the investment task force had also stopped the activities of 73 entities that were alleged to be illegal investments and could potentially harm the community. This illegal investment offer is harmful to the economic society because Perpetrators utilize the incomprehension of some people to invest by offering unreasonable returns or profits. Meanwhile, the activities and products offered are not licensed because the intention of the perpetrators is to get the maximum profit from the society. ${ }^{10}$

As a result, the OJK asked the illegal Fintech lending company to: stop the Lending Fintech activities; remove all the application of money lending technology-based offering; resolve all obligations to users; and submit registration to the OJK immediately. In addition, the OJK Investment Alert Task Force asked the public not to carry out activities with these unlicensed entities because they were not under the supervision of the OJK and could potentially harm the people. This illegal Fintech Lending activity has the potential to harm the people as consumers both material and immaterial. Some of the behavior of the illegal Fintech Lending Companies that caused damages for the consumer includes unethical billing methods, misused of consumer personal data, and debt collect using all consumer contact numbers that caused

8 Otoritas Jasa Keuangan, "Statistik Fintech lending-Maret 2019", https://www.ojk.go.id/id/kanal/iknb/data-danstatistik/fintech/Pages/Statistik-Fintech-Lending-Periode-Maret-2019.aspx

9 Otoritas Jasa Keuangan, "Perusahaan Fintech Lending berizin dan Terdaftar di OJK Per April 2019" Jakarta, 2019, https://www.ojk.go.id/id/berita-dan-kegiatan/publikasi/Documents/Pages/Penyelenggara-FintechTerdaftar-di-OJK-per-8-April-2019/Penyelenggara\%20Fintech\%20Terdaftar\%20April\%202019.pdf

10 Otoritas Jasa Keuangan, "Satgas Waspada Investasi, Siaran Pers SP-02/III/SWI/2019, Satgas Waspada Investasi Hentikan kegiatan 168 Entitas Fintech Ilegal dan 47 Entitas Investasi Ilegal," https://www.ojk.go.id/id/beritadan-kegiatan/siaran-pers/Documents/Pages/Forms/AllItems/SIARAN\%20PERS-

SATGAS\%20WASPADA\%20INVESTASI\%20HENTIKAN\%20KEGIATAN\%20168\%20ENTITAS\%20FINT ECH\%20ILEGAL\%20DAN\%2047\%20ENTITAS\%20INVESTASI\%20ILEGAL\%20.pdf 
inconveniences to consumers. There is one case, if consumers use certain numbers for billing it will end up with discharged from their offices. ${ }^{11}$ On the other side, OJK could not supervise and provide optimal protection to consumers on the grounds that the Fintech Lending Company was not registered by the OJK. Another result, the goal of Fintech lending that is expected to be an alternative financing for non-bankable business actors such as MSMEs is not achieved. In addition, the Fintech Association as a forum not subject to Fintech regulations issued by the OJK and guidelines issues illegal Fintech for Fintech business entity. The Indonesian Fintech Association has issued a code of conduct for responsible lending as a behavioral guideline while at the same time affirming the commitment of businesses in implementing business practice standards that are responsible for protecting customers. ${ }^{12}$

Refers to the Master Plan of Financial Services Sector 2015-2019, OJK has 3 main focuses related to Fintech regulations, namely: stability, inclusiveness and contribution. OJK needs to ensure that fintech does not caused the financial service sector instability (stability). Furthermore OJK wants to build financial inclusion with Fintech which is able to reach the community, provide financial literacy and create efficiency (inclusive) and encourage Fintech to contribute to national economic financing (contributive). ${ }^{13}$

According to with OJK policy, Bank Indonesia as the monetary authority that regulates and supervised the Fintech activities that related to the payment system (Fintech Payment) considers that the development of Fintech Payment has potential risks that if not properly mitigated can disrupt the financial system. Financial technology ecosystems need to be continuously monitored and developed to support the creation of monetary stability, financial system stability, and payment systems that are efficient, smooth, safe, and reliable to support sustainable and inclusive national economic growth. In addition, Bank Indonesia's policy as stated in PBI No. 19/12 / PBI / 2017 also considers that the implementation of financial technology must apply the principles of consumer protection and risk management and has to be prudence while taking into account the expansion of access, national interests, and applicable international standards and practices; and the necessity of policies concerning the development

11 Kumparan Bisnis, “Kecewanya Korban Fintech Illegal Yang Tidak dilindungi oleh OJK”, Accessed February 4, 2019, https://kumparan.com/@ kumparanbisnis/kecewanya-korban-fintech-ilegal-yang-tak-dilindungi-ojk1549287066146116244.

12 Marsya Nabila, "Asosiasi Fintech Resmikan Pedoman Perilaku, Muat Tiga Pilar Perlindungan Konsumen", Daily Social, Last modified August 23, 2018, https://dailysocial.id/post/asosiasi-fintech-resmikan-pedomanperilaku-muat-tiga-pilar-perlindungan-konsumen.

13 Widyo Gunadi, Regulasi Fintech Pada Era Industri 4.0, OJK, presented at Politeknik Negeri Surabaya, November 9, 2018. 
of financial technology that remains synchronously, harmonize and integrated with other Bank Indonesia policies such as the implementation of payment transaction processing and national payment gateways and need to be coordinated with the relevant authorities. ${ }^{14}$ It can be concluded that on the other side the community needs Fintech, but on the other side there are still many Fintech companies that are not comply with regulations, so they have potentially harmful to the society. This is a challenge for both OJK and BI as an authority to continue to strengthen the regulations so that Fintech can be regulated and monitored and becomes a tool to increase a financial inclusion.

The challenge for a financial innovation is system failures, misinformation, errors transaction, personal data security, the application of the KYC (know your customer) principle, the inclusion of exoneration clauses and the handling of consumer complaints. In addition, the most harmful threat is the of cybercrime that can eliminate customer reliance. Meanwhile, the regulations that govern these matters are scattered in many regulations, and may even involve different authorities. Therefore, this study aims to assess the strengthening of the Fintech regulation to take advantage of opportunities while addressing the challenges of financial technology development to empowerment of financial inclusion from a legal perspective.

\section{Methods}

The research method is used to assess the legal issues related to Fintech activities in Indonesia using the method of normative juridical approach. The data used is secondary data of primary, secondary and tertiary legal substances. While the research specifications are descriptive analytical. Furthermore, data obtained, especially secondary data is analyzed using qualitative juridical method.

\section{Result and Discussion}

The National Inclusive Financial Strategy (SNKI) aims to improve public access to formal financial services through an understanding of financial systems, products and services as well as the availability of quality formal financial services Timely, seamless, and safe at an affordable cost according to the needs and capabilities in order to improve the welfare of the community. Many benefits that can be enjoyed by the people, regulators, governments and private parties of

14 The preamble section PBI No. 19/12/PBI/2017 about Penyelenggaraan Teknologi Finansial. 
financial inclusion, such as: ${ }^{15}$ improve economic efficiency; support financial system stability; reduce shadow banking or irresponsible finance; to support the deepening of financial markets; to provide new market potential for banking; support the improvement of Indonesia Human Development index (HDI); positive contribution to sustainable local and national economic growth; reduce the gaps (inequality) and rigidity of low-income trap, so as to improve the welfare of the community that ultimately leads to a decline in poverty levels.

Although financial inclusion includes all segments of society, the financial inclusion activities are focused on groups that have not been met by formal financial services i.e. lowincome communities, the micro and small enterprises and the people such as migrant workers, women, communities in disadvantaged areas. One of the financial accesses that need to be improved is access to credit or financing. Efforts to create financial inclusive include by expanding the access and use of financial systems through technological innovation.

Nowadays, the Indonesian financial industry both conventional and sharia are undergoing rapid changes and developments due to innovation in the technology-based financial sector (Fintech). FinTech is defined as technology-enabled innovation in financial services that could result in new business models, applications, processes or products with an associated material effect on the provision of financial services. While the broad term "FinTech" can be useful to describe a wide range of innovations, further specificity is needed for individual innovations. In this light, it is useful to classify FinTech developments by the main existing economic functions they provide. This is helpful for two reasons: first, it draws out the financial stability implications of FinTech as compared to the existing financial market structure and, second, it places the focus of analysis on the activities and outcomes rather than on the FinTech service providers or underlying technologies. ${ }^{16}$ Technological developments should reduce the cost and enhance the security and convenience of dedicated digital media. There is a clear need to ensure open markets, minimizing the effect of switching costs, and police the pricing structures of both new and old transaction media. Regulation and supervision of payments markets should do much to promote the development of digital money. ${ }^{17}$

\footnotetext{
15 Bank Indonesia, "Keuangan Inklusif - Mengapa Perlu Keuangan Inklusif”, https://www.bi.go.id/id/perbankan/keuanganinklusif/Indonesia/Contents/Default.aspx

16 "Financial Stability Board, Financial Stability Implication from Fintech: Supervisory and Regulatory Issues that Merit Authorities' Attention",http://www.fsb.org/2017/06/financial-stability-implications-from-fintech/.

17 Seetha Devi, "Prospect Of E-Finance in Financial Service Industry," Journal of Emerging Technologies and Innovative Research 6, Issue 1 (2019): 271.
} 
The impacts of Indonesia's Fintech industry growth is the Financial Services Authority $(\mathrm{OJK})$ and Bank Indonesia (BI) as monetary authorities responded and issued regulations as the legal basis for Fintech activities in Indonesia. Service Authority Finance has issued 3 Regulations related to Fintech activities, namely: 1) OJK Regulation No. 77 / OJK.01 / 2016 Information Technology Based Lending and Borrowing Services (Fintech Lending); 2) POJK No. 13 / POJK.02 / 2018 concerning Digital Financial Innovation in the Financial Services Sector and POJK No. 37 / POJK.04 / 2018 Regarding Funds Services through Information Technology-Based Share Offerings (equity crowdfunding). This Equity Crowdfunding is a financial services activity in the Capital Market sector which is also under the supervision of the OJK. However, equity crowdfunding has the same goal as Fintech Lending, which is to provide financial resources and investment facilities for the community. Meanwhile, Bank Indonesia issued Bank Indonesia Regulation (PBI) No. 19/12 / PBI / 2017 Concerning the Implementation of Financial Technology and Regulation of the Board of Governors (PDAG) concerning financial technology and the Regulatory Sandbox. This Fintech arrangement by BI is related to the payment system. Thus, Fintech regulation by BI has a broader understanding when compared to POJK which specifically regulates Fintech Lending. Article 1 Number 1 PBI No. 19/12 / PBI / 2017 defines Financial Technology as: "The use of technology in the financial system that produces new products, services, technology and / or business models and can have an impact on monetary stability, financial system stability, and / or efficiency, smoothness, payment system security and reliability. " Based on these rules, both the OJK and BI in principle aim to regulate and supervise so that the use of technology in the financial sector can: 1) fulfill or provide maximum benefits for the interests and fulfill the community's needs for financial access and payment systems; 2) protect consumers and risk mitigation; 3) support sustainable and inclusive national economic growth. The regulation of financial technology is expected to continue to provide space for innovation in financial technology providers while still applying the principles of consumer protection, risk management and prudential principles. However, in practice the development of information technology-based financial services has the potential to harm the people if it is not properly monitored and regulated. That is why the existence of Fintech needs to be regulated and supervised so that it is in line with its objectives, especially as an effort to encourage financial inclusion.

Based on data published by Bank Indonesia, currently there are 49 Financial Technology Organizers who have registered at Bank Indonesia, and 2 Registered Regulatory Sandbox 
companies. The Financial Technology Organizers above are those who carry out payment systems, market support or supporting providers that are within the scope of financial technology providers based on PBI Fintech. Registration of Financial Technology Providers at Bank Indonesia does not eliminate the obligations and responsibilities of Financial Technology Providers to carry out the licensing process in accordance with the provisions. Thus, there are two large groups of Fintech activities in Indonesia. First; Fintech Lending that is regulated and supervised by the OJK; and second; Fintech Payment which organizes payment systems, market support or supporting providers whose arrangements and supervision are carried out by Bank Indonesia. In addition to aiming to provide legal protection for consumers, Fintech's regulation aims to strengthen the role of Fintech, especially Fintech Lending as an alternative for businesses, especially MSMEs to obtain financial access. Thus, financial inclusion will be more quickly achieved. Fintech arrangements, especially Fintech Lending, are conducted to anticipate the negative impact of Fintech lending, namely: ${ }^{18}$ (1) can be used for money laundering or terrorism financing; (2) user data or information can be misused; (3) there is no protection for users; potential tax revenue does not exist; (4) can lead to mistrust of Fintech Lending; (5) the legal market share of Fintech Lending is reduced.

Based on the negative impact of Fintech Lending that described above, the registration and licensing obligations of the Fintech companies are a strategic legal step to ensure Fintech activities in Indonesia are in accordance with their objectives. Through licensing and registration, both OJK and BI can conduct supervision, coaching and granting sanctions to Fintech companies that are not complying with the rules. The Financial Stability Board (FSB) as an international institution concerned with global financial stability and reminds the importance of international cooperation to increase awareness of Fintech when conducting risk assessments and periodically developing micro regulation and macro prudential frameworks, include: management of operational risk from third party service providers; reduce cyber risk and monitor the risks of microfinance that can emerge quickly if left unchecked. ${ }^{19}$

In addition, Fintech regulations in Indonesia provide opportunities for the development of the Islamic finance industry to contribute to national economic development. Nowdays, the development of Fintech activities based on Sharia principles has a strong legal basis with the

18 Otoritas Jasa Keuangan, Fintech Peer To Peer Lending, 2018.

19 Financial Stability Board, "Financial Stability Implications From FinTech- Supervisory and Regulatory Issues that Merit Authorities Attention", Last modified June 27, 2017, p. 2, http://www.fsb.org/wpcontent/uploads/R270617.pdf 
issuance of the Fatwa of the National Sharia Council - Indonesian Ulama Council No. 117 / DSN-MUI / II / 2018 About Sharia-based Information Technology-Based Financing Services (Fintech Syariah). Likewise, Islamic finance has the opportunity to participate in poverty alleviation and business empowerment in line with the purpose of Islamic finance through financial inclusion. The opportunity for the Islamic finance industry to enter the Fintech industry is even greater, considering that the financing system for innovative industries or start-up businesses uses the Venture Capital financing scheme, which is essentially temporary capital participation, not borrowing. This makes it easier for the Islamic finance industry, because the contract used is a cooperation contract. In sharia activities, this cooperation is carried out using mudharabah or musyarakah contract. Meanwhile, Fintech lending regulations specifically regulate lending and borrowing, which cannot be used as a legal basis for the operations of Fintech Syariah. Thus, Fintech Syariah refers to the positive law governing financing. Therefore, Fintech regulation reform is needed which explicitly provides space for Fintech Syariah, in addition to the DSN-MUI Fatwa. Based on data as of April 2019, the sharia Fintech Lending Company licensed and registered by OJK, only 4 companies, namely PT Investree Radika Jaya; PT Amanna Fintek Syariah; PT Dana Syariah Indonesia; and PT Danakoo Mitra Artha. ${ }^{20}$ Beyond that, there are still many Fintech Syariah Companies are still in the registration process. To optimize the role of Fintech both conventional and sharia as a means to encourage financial regulation of appropriate regulations and supervision is a key word.

\subsection{Strengthen and Arrangement of Fintech Regulations as an Effort to Promote Financial Inclusion.}

The Regulation has an important role in Fintech activities because of the potential impacts of using information technology. Therefore strengthen and structuring regulations will influence the development of Fintech. Nowdays, the development of Fintech regulations in Indonesia follows the development of usage Fintech in the society. Initially, Fintech as part of digital economic activities was widely used for transactions or payment systems. However its development, Fintech lending was greater than Fintech Payment. The development of Fintech Lending practice has encouraged OJK to issue POJK 77 / POJK.01 / 2016 which regulates Fintech Lending. The presence of POJK Fintech lending is intended to provide protection to

20 Otoritas Jasa Keuangan, "Perusahaan Fintech Lending Berizin dan Terdaftar di OJK Per April 2019" https://www.ojk.go.id/id/berita-dan-kegiatan/publikasi/Documents/Pages/Penyelenggara-Fintech-Terdaftar-diOJK-per-8-April-2019/Penyelenggara\%20Fintech\%20Terdaftar\%20April\%202019.pdf 
Users, Implementation of Technology-based Money Lending and Borrowing Service activities, and protection of national interests while still providing growth space for start-up companies in order to increase financial inclusion in Indonesia. Some of the substances that are strategic issues in POJK involves: 1) provisions to minimize credit risk, 2) protection of customer interests such as misuse of funds and customer data, and protection of national interests such as anti money laundering and prevention of terrorism funding, as well as disruptions on financial system stability. Through POJK Fintech, OJK seeks to limit the activities of illegal Fintech Lending and supervise by regulating the obligations that must be considered by Fintech Organizers, such as: (1) The organizer of fintech is in the form of a legal entity Limited Liability Company or Cooperative (Article 2); (2) Limitation of foreign shares to the Fintech Operator, directly or indirectly, is at most $85 \%$ (Article 3). Foreign parties can participate as lenders, but cannot become loan recipients; (3) Minimum paid-up capital of Rp1,000,000,000 (one billion) at the time of registration, but at the time of submitting an application for licensing of paid-in capital or own capital of at least Rp.2,500,000,000 (two billion five hundred million rupiah); (4) The maximum lending limit is 2 billion; (5) The obligation for the organizer to create an escrow account, meaning the organizer should not contact with the loan funds either from the provider or the borrower, but can raise the commission of each transaction; (6) All Fintech organizers are obliged to apply for registration and licensing (article 7); (7) The legal relationship between the organizer and the lender and the agreement between the lender and the borrower is poured out in the electronic document (e-contract).

According to the requirements, beside POJK Fintech, there are several regulations that will strengthen POJK Fintech Lending. First, Book III in Civil Code about the obligation as a legal based inlending and borrowing agreement in Fintech Lending activity. Civil Code as a general law put the principles in Fintech Lending that will restrict the rights and obligations of the parties. Second, the law No. 11 of 2008 on information and electronic transactions (ITE LAW) as the basis of transactions set forth in electronic documents (e-contracts) as a tool of evidence or legal documents that have strong proof of power in addition to the The law No. 21 of 2011 About the Financial Services Authority has become highly relevant in relation to the functioning of the management, construction and supervision of Fintech Lending by OJK. However, there is a weakness of regulation related to Fintech, namely the absence of a strong legal standing for the costumer personal data protection, which is precisely a crucial issue in Fintech activities. Currently, Fintech consumer protection, especially protection against the use of personal data 
refers to POJK No. 1/POJK. 07/2013 concerning consumer protection of the financial services sector. Article 31 of the POJK prohibits financial services businesses in any way providing data and/or information about its customers to third parties unless the consumer provides written consent and/or is required by regulations Legislation.

The third regulation governing Fintech is PBI No. 19/12/PBI/2017 on the implementation of financial technology. Unlike the POJK Fintech Lending, PBI Fintech regulates the implementation of financial technology related to the payment system that is part of authority of Bank Indonesia's. In addition to payment systems, Bank Indonesia has established and implemented policies in monetary field and financial system stability including macro prudential policies. The regulation, supervision and monitoring of the implementation of financial technology is important so that the implementation of financial technology is properly monitored and directed so that the benefits of this financial technology can be enjoyed by the public. In addition, various risks including the potential for the emergence and development of unsupervised economic transactions (shadow economy) can be properly mitigated. This Bank Indonesia Regulation About Fintech requires financial technology providers to apply the principles of consumer protection and risk management and prudence. When viewed from the provisions of Article 3 Paragraph (1) of the Fintech PBI, what is closely related to the duties of $\mathrm{BI}$ is the implementation of financial technology related to the payment system and market supporters. Based on the explanation of Article 3 Paragraph (1) letter a, the payment system includes authorization, clearing, final settlement, and payment execution. Examples of payment systems include the use of block chain or distributed ledger technology for managing funds transfers, electronic money, electronic wallets, and mobile payments. Whereas "market support" is financial technology that uses financial technology that uses information technology and / or electronic technology to facilitate the provision of faster and cheaper information related to financial products and / or services to the public. Examples of the implementation of financial technology in the market support category include providing comparative data on information on financial products or services. This BI regulation also requires financial technology providers who will or have carried out activities that meet the criteria required to register with BI. Registration obligations are excluded for payment system service providers who have obtained licenses from Bank Indonesia, and / or providers of financial technology that are under the authority of other authorities. Financial technology providers that are under another authority that organizes financial technology in the payment system field are required to register with BI. 
In addition, currently Fintech Investment and Fintech Market Provision are starting to grow. The following is the percentage of Fintech in Indonesia:

Table 1.

Percentage of Fintech Types in Indonesia

\begin{tabular}{clc}
\hline No & \multicolumn{1}{c}{ Type of Fintech } & Percentage \\
\hline 1 & Fintech Lending & $38,2 \%$ \\
\hline 2 & Fintech Payments & $34,5 \%$ \\
\hline 3 & Fintech Market Provision & $18,2 \%$ \\
\hline 4 & Fintech Investment & $9,1 \%$ \\
\hline \multicolumn{2}{l}{ Source } & Departemen Kebijakan Sistem Pembayaran - Bank Indonesia, 2018.
\end{tabular}

According to the data above, the percentage of Fintech Lending on Fintech Payment. This is due to the big potential of Fintech Lending market due to the magnitude of financing gap in Indonesia (unbanked \& MSMES). The growth of Fintech is reach $16.3 \%$ per year shows that Fintech will be an alternative way to financing, payment systems, investments and market supporters in the future. Therefore, strengthen and structuring an integrative regulation will be the tools to direct Finctech's activities to promote financial inclusion.In addition, strengthening and structuring this regulation is urgent to anticipate the vulnerable side of Fintech's activities, including personal data security, vulnerable to money laundering and terrorism financing activities, inclusion of exoneration clauses, and consumer protection. One of the goals of regulatory reform that must be carried out immediately is legal protection against misuse of personal data. $^{21}$

\subsection{The Potential Development of Sharia Fintech to Encourage Financial Inclusion.}

The existence of Sharia Fintech in Indonesia is relatively new compared to conventional Fintech. Nevertheless, sharia Fintech is predicted to develop following the development of Indonesia's Sharia financial industry. There are several reasons for the development of Sharia Fintech. First, due to customer segmentation, Indonesia is the country with the largest Muslim population. At the global level, the development of Indonesia's Sharia finance industry is listed in the 10 largest countries for Sharia finance and ranks 11 with a score of 42 based on the Global Islamic Economy Indicator. In addition, the market potential is still open, considering that

21 Lastuti Abubakar dan Tri Handayani, "Financial Technology: Legal Challenges for Indonesia Financial Sector," IOP Conference Series: Earth and environmental Science $175 \quad$ (2018), https://iopscience.iop.org/article/10.1088/1755-1315/175/1/012204/pdf 
conventional financial institutions, especially banking cannot fulfill all the needs of the people, especially SMES that are considered not bankable. In addition, Sharia Fintech market is quite large considering that more than $95 \%$ of business people in Indonesia are SMES, and about 60$70 \%$ of SMES do not have access to banking financing. During this time, the Persero Bank provides $50 \%$ of the credit or financing for SMES. Furthermore, based on the data from Ministry of Communication and Information, $8 \%$ of SMES businessmen have utilized the online platform in marketing its products. This means that the SME market is an opportunity for sharia Fintech to participate. Second, there is a resemblance to the start-up Fintech financing trend using in the form of Venture Capital. This means that the inclusion of capital becomes the basis of the legal relationship between Fintech Start-up and Venture Capital. This venture capital concept is easier to implement sharia Fintech that uses cooperation instead of lending and borrowing scheme.

As part of the financial services sector, the regulation governing Sharia Fintech refers to the provisions published by both OJK and BI. Although there are no regulations specifically governing sharia Fintech, regulations governing or relating to the implementation or Fintech activities can be used as long as they do not contradict sharia principles and sharia governance. The main sharia prohibitions related to financial transactions are discussed below are : interest (riba); speculation (gambling); unearned income (maysir) and excessive risk /uncertainty (gharar). ${ }^{22}$ In Sharia finance, money is not a commodity but as having time value, the flexibility attitude to how money is treated makes fintech enabled peer-to-peer lending is acceptable in Islamic finance environment.

In addition, the development potential of Sharia Fintech is increasingly given the alternative financing based on sharia principles that can reach SMES and individual consumers are still limited. The legal problem is POJK No. 77/POJK. 01/2016 only set up the lending service based on information technology, so it does not apply to Sharia-based Fintech financing. It is not appropriate to incorporate sharia Fintech into the interest-based borrowing service. The development of Fintech regulation based on sharia principles is newly incorporated into the explanation of article 3 (g) POJK No. 13/POJK. 02/2018 concerning Digital Financial innovation (IKD) explaining that what is meant by "other Digital financial supporters" Among other social/eco crowdfunding, Islamic Digital financing, E-Waqf, E-zakat, robo advice and

\footnotetext{
22 Maria Todorof, "Syariah-Compliant Fintech in the Banking Industry." ERA forum 18: 1-7, p.4,
} https://doi.org/10.1007/s12027-018-0505-8 
credit scoring. In the future, the legal basis for the existence of sharia Fintech still need strengthening to fulfill sharia principles and sharia governance, which emphasizes transparency to avoid the uncertainty (gharar) and profit-based benefits. Things need to be done by the OJK and BI to optimize Fintech sharia is doing financial literacy to promote a sustainable financial inclusion, based on the results of research there are a positive and significant correlation between financial inclusion and SMEs. ${ }^{23}$

\section{Conclusions}

Financial Inclusion is the most important part in achieving the sustainable development goals, especially to overcome the poverty issue, promoting economic growth and to create an impartiality the condition of economic. Through financial inclusion, the people will get the access to the financial system can be realized. One of the efforts made is applying the principles of innovation that encourage technological and institutional innovation as a means to expand access and use of the financial system (financial technology).

The rapid development of financial Technology (Fintech) in Indonesia became an interesting alternative for the people, especially for unbanked people and SMES. They have an access to be financed from the other financial Institution besides the banks. However, it is necessary to strengthen and arranged the regulation to be the legal basis for FINTECH activities in order to decrease any harmful effect to the society. Sharia Fintech has the opportunity to utilize customer segmentation as the largest Muslim society country and have so many enterprises in micro and small. In addition, there is a similarity between the trends of Fintech start-up that absorbs venture capital funds based on equity participation with sharia contract.

\section{References}

Abubakar, Lastuti dan Handayani. "Financial Technology : Legal Challenges for Indonesia Financial Sector”. IOP Conference Series : Earth and environmental Science 175, (2018). https://iopscience.iop.org/article/10.1088/1755-1315/175/1/012204/pdf

Alvianolita, Poppy. et.al.“Pengaruh Literasi keuangan dan Inklusi Keuangan Terhadap Kinerja Usaha Kecil di Kalimantan Timur.” Jurnal Economia 15, No.1 (2019).

Bank Indonesia, "Keuangan Inklusif - Mengapa Perlu Keuangan Inklusif." https://www.bi.go.id/id/perbankan/keuanganinklusif/Indonesia/Contents/Default.aspx

23 Poppy Alvianolita,et.al, "Pengaruh Literasi keuangan dan Inklusi Keuangan Terhadap Kinerja Usaha Kecil di Kalimantan Timur.” Jurnal Economia 15, No.1 (2019): 56. 
Bank Indonesia, "Stabilitas Sistem Keuangan - Keuangan Inklusif - Apa, Mengapa, Bagaimana dan Siapa." https://www.bi.go.id/id/perbankan/keuanganinklusif/Indonesia/Contents/Default.aspx

Durai, Tabitha. "Digital Finance And Its Impact On Financial Inclusion.” Journal of Emerging Technologies and Innovative Research (JETIR) 6, Issue 4 (2019)

Financial Stability Board (2017), "Financial Stability Implication from Fintech: Supervisory and Regulatory Issues that Merit Authorities' Attention", Access from: http://www.fsb.org/2017/06/financial-stability-implications-from-fintech/

Gunadi, Widyo. Regulasi Fintech Pada Era Industri 4.0, OJK, Presented in Politeknik Negeri Surabaya, November 9, 2018.

Kumparan Bisnis “Kecewanya Korban Fintech Illegal Yang Tidak dilindungi oleh OJK”,Last modified February 4, 2019, https://kumparan.com/@kumparanbisnis/kecewanya-korbanfintech-ilegal-yang-tak-dilindungi-ojk-1549287066146116244.

Nabila, Marsya. “Asosiasi Fintech Resmikan Pedoman Perilaku, Muat Tiga Pilar Perlindungan Konsumen.”Daily Social.Last modified $\quad$ August 23, 2018, https://dailysocial.id/post/asosiasi-fintech-resmikan-pedoman-perilaku-muat-tiga-pilarperlindungan-konsumen

OJK. "Perusahaan Fintech Lending Berizin danTerdaftar di OJK Per April 2019." Last modified 2019. https://www.ojk.go.id/id/berita-dankegiatan/publikasi/Documents/Pages/Penyelenggara-Fintech-Terdaftar-di-OJK-per-8April-2019/Penyelenggara\%20Fintech\%20Terdaftar\%20April\%202019.pdf

Otoritas Jasa Keuangan. "Master Plan of Indonesia Financial Institution year 2015-OJK." Jakarta: OJK, 2019.

Otoritas Jasa Keuangan. "Perusahaan Fintech Lending berizin dan Terdaftar di OJK Per April 2019." Last modified 2019. https://www.ojk.go.id/id/berita-dankegiatan/publikasi/Documents/Pages/Penyelenggara-Fintech-Terdaftar-di-OJK-per-8April-2019/Penyelenggara\%20Fintech\%20Terdaftar\%20April\%202019.pdf

Otoritas Jasa Keuangan. "Statistik Fintech lending - Maret 2019." Last modified 2019. https://www.ojk.go.id/id/kanal/iknb/data-dan-statistik/fintech/Pages/Statistik-FintechLending-Periode-Maret-2019.aspx

PBI No. 19/12/PBI/2017 on Implemetation of Financial Technology .

POJK No. 77/POJK.01/2016, on Peer To Peer Lending with Financial Technology based, 2018. 
Sanjaya, I Made dan Nursechafia. "Inklusi Keuangan dan Pertumbuhan Inklusif: Analisis Antara Provinsi di Indonesia."Buletin Ekonomi Moneter dan Perbankan 18, No. 3(2016).

Sari. Fitri Rusdiana. "Peran Inklusi Keuangan melalui Integrasi Fintech dalam Stabilitas Sistem keuangan Indonesia.”Jurnal Ekonomi Kuantitatif Terapan 11, No. 2(2018).

Satgas Waspada Investasi. "Siaran Pers SP-02/III/SWI/2019, Satgas Waspada Investasi Hentikan kegiatan 168 Entitas Fintech Ilegal dan 47 Entitas Investasi Ilegal.” Last modified 2019. https://www.ojk.go.id/id/berita-dan-kegiatan/siaranpers/Documents/Pages/Forms/AllItems/SIARAN\%20PERS-

SATGAS\%20WASPADA\%20INVESTASI\%20HENTIKAN\%20KEGIATAN\%20168\%2 0ENTITAS\%20FINTECH\%20ILEGAL\%20DAN\%2047\%20ENTITAS\%20INVESTASI \%20ILEGAL\%20.pdf

Seetha, Devi. "Prospect Of E-Finance in Financial Service Industry." Journal of Emerging Technologies and Innovative Research 6, Issue 1 (2019).

Todorof, Maria. "Syariah-Compliant Fintech in the banking industry." ERA Forum 18 (2018): 17, p. 4. https://doi.org/10.1007/s12027-018-0505-8 